\title{
Myxobiota of the Brazilian Atlantic Forest: species on oil palm tree (Elaeis guineensis, Arecaceae)
}

\author{
Mixobiota da Floresta Atlântica brasileira: espécies em dendezeiro \\ (Elaeis guineensis, Arecaceae)
}

Clebson Firmino da Silva ${ }^{1} \&$ Laise de Holanda Cavalcanti ${ }^{2}$

\begin{abstract}
Elaeis guineensis Jacq. (Arecaceae), the oil palm tree, serves as a phorophyte for many different groups of organisms, some of which help decompose organic matter coming from the organs of the tree itself or from remains of other plants retained in leaf sheaths. To study the myxobiota of E. guineensis, we examined living and dead trunks, leaves, bracts and inflorescences in the Gurjaú Ecological Reserve, in the township of Cabo de Santo Agostinho, Pernambuco, Brazil. Incidence and species abundance were determined in three Atlantic forest fragments. The reported species are listed herein, followed the known distribution of each species in Brazil, and which of them occur on palm trees. All of the subclasses and five orders were recorded and 22 species were added to the list of myxomycetes associated with oil palm trees in Brazil. The highest incidence value was recorded on dead leaves. Ceratiomyxa fruticulosa (O. F. Müll.) T. Macbr., Arcyria cinerea (Bull.) Pers. and Physarum compressum Alb. \& Schwein. were the most common species, while Hemitrichia serpula (Scop.) Rostaf. ex Lister showed the highest levels of abundance and incidence, thus confirming its preference for the substrates provided by palm trees.
\end{abstract}

Key words: tropical forest, microhabitat, Myxomycetes, palm tree.

\section{Resumo}

Elaeis guineensis Jacq. (Arecaceae), o dendezeiro, serve como forófita para diferentes grupos de organismos e alguns deles atuam na decomposição da matéria orgânica proveniente de órgãos da própria árvore ou de restos de outras plantas retidos pelas bainhas foliares. A mixobiota de E. guineensis foi estudada examinando-se troncos, folhas, brácteas e inflorescências vivos e mortos na Reserva Ecológica do Gurjaú, município de Cabo de Santo Agostinho, estado de Pernambuco, Brasil. Foram determinadas a incidência e a abundância das espécies em três fragmentos de Floresta Atlântica. As espécies foram listadas, indicando-se a distribuição conhecida para o Brasil assim como seus registros para palmeiras no país. Todas as subclasses e cinco ordens foram registradas e 22 espécies foram adicionadas à lista de mixomicetos associados a dendezeiro no Brasil. O valor de incidência mais elevado foi registrado para folhas mortas. Ceratiomyxa fruticulosa (O. F. Müll.) T. Macbr., Arcyria cinerea (Bull.) Pers. e Physarum compressum Alb. \& Schwein. estavam frequentemente presentes. Hemitrichia serpula (Scop.) Rostaf. ex Lister mostrou os níveis mais elevados de abundância e incidência, confirmando sua preferência em associar-se a palmeiras.

Palavras-chave: floresta tropical, microhabitat, Myxomycetes, palmeira.

\section{Introduction}

The oil palm tree (Elaeis guineensis Jacq.) arrived in Brazil, where it spread rapidly and is popularly known as dendezeiro, with the African slaves during the colonial period. Although it is exotic, it has been integrated into both the landscape and the culture of northeastern Brazil. In addition to the traditional use of the oil obtained from its fruit pulp and almond in industry and cooking, the recent use of its oil as biofuel makes it economically very important. At present, it is also used as an ornamental tree in streets, parks, and plazas in Pernambuco and other states (Lorenzi et al. 1996). This species can be found in fragments of the

\footnotetext{
${ }^{1}$ Programa de Pós-Graduação em Ciências Biológicas, Centro de Ciências Biológicas (CCB), Universidade Federal de Pernambuco, Av. Prof. Moraes Rego s/n, Cidade Universitária, 50.670-90, Recife, PE, Brasil.

${ }^{2}$ Professor Titular, Departamento de Botânica, CCB, UFPE; Pesquisador CNPq 1A. Apoio financeiro: CNPq. Autor para correspondência: laise@pq.cnpq.br
} 
Atlantic Forest in the Northeast Region and it is included in the list of mystical-religious plants used in the Afro-Brazilian umbanda and candomblé religious rituals (Albuquerque 1997).

The oil palm tree serves as a phorophyte (primary substrate) for several different groups of living organisms, some of which, including myxomycetes, help decompose organic matter coming from organs of the tree itself or from remains of other plants that are retained by leaf sheaths that remains attached to the trunk after senescence.

Except for the brief references by Farr (1960), Pôrto et al. (1985), Ribeiro et al. (2002) and Cavalcanti et al. (2006), there are no record of the association of myxomycetes and E. guineensis in the studies conducted in Brazil. Yet, approximately one hundred species of myxomycetes have been reported as associated with palm trees in both dry and humid forests (Alves \& Cavalcanti 1996; Cavalcanti \& Putzke 1998; Mobin \& Cavalcanti 1998, 1999 a, b, 2000, 2001; Cavalcanti \& Mobin 2004).

To contribute to the knowledge on the microhabitats available to myxomycetes in the Atlantic Forest and continue the ongoing survey of specimens of this group associated with palm trees in Brazil, a study of the incidence of sporocarps on the different organs of individuals of Elaeis guineensis growing in fragments of Atlantic Forest was carried out.

\section{Material and Methods}

The incidence of myxomycetes on Elaeis guineensis along with the distribution and abundance of sporocarps on trunks, leaves, bracts, inflorescences, and fruits (living or dead) were analyzed in the Café (6.852 ha), Cuxio (118.457 ha), and São Braz (37.068 ha) forests, in the Gurjaú Ecological Reserve ( $8^{\circ} 14^{\prime} 21,7^{\prime \prime}$ 'S and $\left.35^{\circ} 03^{\prime} 00,4^{\prime \prime} \mathrm{W}\right)$, municipality of Cabo de Santo Agostinho, in the humid forest subzone of the state of Pernambuco.

The material collected (63 specimens) was curated and representative exsiccates were deposited at the UFP Herbarium. Species identification used the keys and descriptions found in Martin \& Alexopoulos (1969), Farr (1976), and Lado \& Pando (1997). The classification used follows that of Martin et al. (1983).

Species were listed alphabetically by genus under each subclass, together with their known distribution in Brazil according to Cavalcanti (2002), Maimoni-Rodella (2002), Putzke (2002), Bezerra et al. (2008 a,b), Cavalcanti et al. (2006, 2008), Bezerra et al. (2009), Costa et al. (2009), and Tenório et al. (2009), and the records of associations with other species of palm trees in this country.

The incidence percentage per individual and plant organ serving as a substrate was calculated; abundance was evaluated for each species according to the criteria of Novozhilov et al. (2001), which is based on the relationship between the number of specimens for a given taxon and the total number of records of myxomycetes for the substrate analyzed. Accordingly, the species were placed into the following categories: $\mathrm{R}-$ rare $(0.5-1 \%), \mathrm{O}-$ occasional (2-4\%), C - common (5-7\%), and A abundant (over 7\%). The following data were listed after the name of each species: abundance, number of records obtained for each organ (Bct- bract; Trktrunk; Lf - leaf; Ifl - inflorescence), and whether the organ was living (Lv) or dead (Dd).

The acronyms of the Brazilian states are AC $=$ Acre $; \mathrm{AL}=$ Alagoas $; \mathrm{AM}=$ Amazonas; $\mathrm{AP}=$ Amapá; $\mathrm{BA}=$ Bahia; $\mathrm{CE}=$ Ceará; $\mathrm{DF}=$ Distrito Federal; $\mathrm{MA}=$ Maranhão MG = Minas Gerais; $\mathrm{PA}$ $=$ Pará PB = Paraíba $; \mathrm{PE}=$ Pernambuco $; \mathrm{PI}=$ Piauí; $\mathrm{PR}=$ Paraná; $\mathrm{RJ}=$ Rio de Janeiro; $\mathrm{RN}=$ Rio Grande do Norte; RR = Roraima; RS = Rio Grande do Sul; $\mathrm{SC}=$ Santa Catarina; $\mathrm{SP}=$ São Paulo.

\section{Results and Discussion}

In the Brazilian literature consulted, 101 species of myxomycetes have been reported as associated with palm trees. Of these, only Physarum compressum Alb. \& Schwein., Fuligo cinerea (Schw.) Morgan, Physarella oblonga (Berk. \& M. A. Curtis) Morgan and Hemitrichia pardina (Minakata) Ing were cited as occurring on $E$. guineensis (Farr 1960; Cavalcanti et al. 2006).

Five of the six orders and $50 \%$ of the families recognized for this class by Martin et al. (1983) are represented among the 63 specimens collected in the present study. These records increase the number of species of myxomycetes reported on oil palm tree to 25, two of which, Ceratiomyxa sphaerosperma Boedijn and Didymium anellus Morgan, had never been recorded as occurring on any species of palm tree in Brazil.

\section{List of taxa associated to Elaeis guineensis}

Ceratiomyxomycetidae - This subclass comprises only the order Ceratiomyxales, with a single family and genus including four species (Lado 2001). Two species were recorded in this study. 
Ceratiomyxa fruticulosa (O.F. Müll.) T. Macbr., N. Amer. Slime-Moulds: 18 (1899).

(C) (4/LfDd, 1/IflDd)

Cosmopolitan and widely distributed in Brazil, this species had already been recorded on palm trees in the states of Ceará and Piauí (Alves \& Cavalcanti 1996; Mobin \& Cavalcanti 2000; Cavalcanti \& Mobin 2004). In this study, the specimens were found on dead leaves and inflorescences (Tabs. 1-2); it was common on oil palm trees in the São Braz and Café Forests.

Records of associations with palm tree species in Brazil: Astrocaryum vulgare Mart.; Attalea speciosa Mart. ex Spreng.; Copernicia prunifera (Miller) H. E. Moore.

Distribution in Brazil: North (AM, AP, PA, RR), Northeast (AL, BA, CE, PB, PE, PI, RN, SE), Southeast (SP), South (RS, SC).

Ceratiomyxa sphaerosperma Boedijn, Misc. Zool. Sumatr. 24:1 (1927). (O) (2/IflDd)

Predominantly tropical and rarely cited in Brazil, C. sphaerosperma has been reported to occur as a lignicolous species in the Atlantic and Amazonian forests (Farr 1985; Cavalcanti 2002; Cavalcanti et al. 2008). In this study, it was only recorded in the São Braz Forest, where it was occasionally found on dead inflorescences of oil palm trees (Tabs. 12 ); both specimens were very typical. This is a new record on palm trees in Brazil.

Distribution in Brazil: North (AM, PA, RR), Northeast (BA, PB, PE, SE).

Myxogastromycetidae - This subclass comprises the orders Echinosteliales (not recorded in this study), Liceales, Trichiales, and Physarales, with a total of 10 families, 42 genera, and 671 species (Lado 2001). In this study, 19 species belonging to the families Cribrariaceae (Cribraria), Trichiaceae (Arcyria, Hemitrichia, Metatrichia, Perichaena), Didymiaceae (Didymium) and Physaraceae (Physarella, Physarum) were recorded on oil palm trees.

Arcyria cinerea (Bull.) Pers., Syn. Meth. Fung. 184 (1801). (C) (1/TrkDd, 2/TrkLv, 1/IflDd, 1/LfDd)

This is a cosmopolitan species distributed in all regions of Brazil that was found on palm trees in the states of Pernambuco, Ceará and Piauí (Pôrto et al. 1985; Alves \& Cavalcanti 1996; Mobin \& Cavalcanti 2001). This species presents great morphological variations and, in the studied material, the variation in sporocarp size is striking. However, these characteristics are typical of the species, which is common on oil palm trees, where it develops on several different organs (Tabs. 1-2).

Records of associations with palm tree species in Brazil: A. vulgare; A. speciosa; Cocos nucifera L.; Mauritia flexuosa L. f.

Distribution in Brazil: North (AC, AM, PA, RR), Northeast (AL, BA, CE, PB, PE, PI, RN, SE), Southeast (RJ, SP), South (PR, SC, RS).

Cribraria microcarpa (Schrad.) Pers., Syn. Meth. Fung.: 190 (1801). $\quad$ (O) $(1 /$ TrkLv, 2/LfDd)

A cosmopolitan species, C. microcarpa is found in all regions of Brazil, but has only been reported to occur on palm trees in the state of Piauí (Mobin \& Cavalcanti 1998; Cavalcanti \& Mobin 2004). In this study it was occasionally found on oil palm trees (Tab. 2) of the Café Forest, and the specimens analyzed, obtained on dead leaves and living trunks (Tab. 1), presented the typical characteristics of this species.

Records of associations with palm tree species in Brazil: A. vulgare; M. flexuosa.

Distribution in Brazil: North (RR), Northeast (BA, CE, PB, PE, PI, RN, SE), Southeast (SP), South (PR).

Didymium anellus Morgan, J. Cincinnati Soc. Nat. Hist. 16: 148 (1894). $\quad$ (C) (1/BctDd, 3/IflDd)

Until 2005, this species had only been recorded in the state of São Paulo (Hochgesand \& Gottsberger 1996). Cavalcanti et al. (2006) reported $D$. anellus for the first time in the Northeastern region. This is the first record of $D$. anellus on palm trees in Brazil. The characteristics of the sporocarps -long plasmodiocarps or globose, sessile sporangia- are typical of this species. All the specimens were collected in the São Braz Forest, where it was common on oil palm trees.

Distribution in Brazil: Southeast (SP), Northeast (PE).

Didymium clavus (Alb. \& Schw.) Rabenh., Deutschl. Krypt.-Fl. 1:280 (1844). （R) (1/IflDd)

Recorded in a few states in northern and northeastern Brazil, D. clavus was found solely on palm trees in Piauí, in savanna ("cerrado") and alluvial forest environments (Mobin \& Cavalcanti 1999a, 2000; Cavalcanti \& Mobin 2004). In this study, it was rare on oil palm trees and was recorded only on an inflorescence (Tabs. 1-2) in the Cuxio Forest.

Records of associations with palm tree species in Brazil: A. vulgare; C. prunifera.

Distribution in Brazil: North (RR), Northeast (BA, PB, PE, PI, SE). 
Table 1 - Incidence of myxomycetes on the different organs of Elaeis guineensis Jacq., based on data colleted in the Gurjaú Ecological Reserve, Pernambuco State, Brazil. Note: Dd = dead, Lv = living.

\begin{tabular}{|c|c|c|c|c|c|c|c|c|c|}
\hline \multirow[t]{2}{*}{ Species } & \multicolumn{2}{|c|}{ Bract } & \multicolumn{2}{|c|}{ Leaf } & \multicolumn{2}{|c|}{ Inflorescence } & \multicolumn{2}{|c|}{ Trunk } & \multirow[b]{2}{*}{ Total } \\
\hline & Dd & $\mathbf{L v}$ & Dd & $\mathbf{L v}$ & Dd & $\mathbf{L v}$ & Dd & $\mathbf{L v}$ & \\
\hline Ceratiomyxa fruticulosa (O.F. Müll.) T. Macbr. & & & 4 & & 1 & & & & 5 \\
\hline Ceratiomyxa sphaerosperma Boedijn & & & & & 2 & & & & 2 \\
\hline Arcyria cinerea (Bull.) Pers. & & & 1 & & 1 & & 2 & 2 & 6 \\
\hline Cribraria microcarpa (Schrad.) Pers. & & & 2 & & & & & 1 & 3 \\
\hline Didymium anellus Morgan & 1 & & & & 3 & & & & 4 \\
\hline Didymium clavus (Alb. \& Schw.) Rabenh. & & & & & 1 & & & & 1 \\
\hline Didymium sp. & & & & & 3 & & & & 3 \\
\hline Hemitrichia pardina (Minakata) Ing & & & & & 1 & & & & 1 \\
\hline Hemitrichia serpula (Scop.) Rostaf. ex Lister & & & 7 & & & & 1 & 2 & 10 \\
\hline $\begin{array}{l}\text { Metatrichia vesparia (Batsch) Nann.-Bremek. } \\
\text { ex G. W. Martin \& Alexop. }\end{array}$ & & & 4 & & & & & & 4 \\
\hline Perichaena chrysosperma (Curr.) Lister & & 1 & & & & & & & 1 \\
\hline Physarella oblonga (Berk. \& M. A. Curtis ) Morga & & & & & & & 3 & & 3 \\
\hline Physarum album (Bull.) Chevall. & & & 1 & & & & & & 1 \\
\hline Physarum bogoriense Racib. & 1 & & 2 & & & & & & 3 \\
\hline Physarum compressum Alb. \& Schwein. & & & & & 5 & & & & 5 \\
\hline Physarum crateriforme Petch. & & & & & 1 & & & & 1 \\
\hline Physarum gyrosum Rostaf. & & & & & & & & 1 & 1 \\
\hline Physarum stellatum (Massee) G.W. Martin & & & 1 & & & & & & 1 \\
\hline Physarum viride (Bull.) Pers. & & & 2 & & & & & & 2 \\
\hline Physarum sp. 1 & & & 1 & & & & & & 1 \\
\hline Physarum sp. 2 & & & 1 & & & & & & 1 \\
\hline Stemonitis fusca Roth & & & 2 & & & & & & 2 \\
\hline Stemonitis splendens Rostaf. & & & & & & & & 1 & 1 \\
\hline Stemonitopsis typhina (F.H. Wigg.) Nann.-Bremek. & & & & & & & & 1 & 1 \\
\hline Total & 2 & 1 & 28 & 0 & 18 & 0 & 6 & 8 & 63 \\
\hline
\end{tabular}

\section{Didymium sp.}

(O) (3/IflDd)

The three specimens encountered on the inflorescences (Tab. 1) of a single oil palm tree in the Cuxio Forest clearly belong to the complex encompassing $D$. nigripes, $D$. bahiense, and $D$. iridis, yet they could not be identified to species because they lacked the columella typically found in such species.

Hemitrichia pardina (Minakata) Ing, Myxomycetes Britain and Ireland: 132 (1999).

(R) (1/IflDd)

Although this species is rarely collected, it seems to be common in the Neotropical region, where it occurs on leaves and bark of living trees. Rarely collected in Brazil and on oil palm trees (Cavalcanti et al. 2006), a single specimen was found in this study, in the Café Forest, on inflorescences along with sporocarps of a member of Physarales (Tabs. 1-2). Sporocarps were very typical, with conspicuous dark projections on the peridium. Only their pedicel size varied and it was longer than in the descriptions found in the literature.

Records of associations with palm tree species in Brazil: E. guineensis.

Distribution in Brazil: Northeast (PE).

Hemitrichia serpula (Scop.) Rostaf. ex Lister, Monogr. Mycetozoa 179 (1894)

(A) (1/TrkDd, 2/TrkLv, 7/LfDd)

Cosmopolitan and widely distributed in all regions of Brazil, $H$. serpula is frequently cited as occurring on palm trees in Brazil and other countries, such as Cuba, Equatorial Guinea, and Puerto Rico (Vilaró 1991; Lado \& Teyssière 1998; Mobin \& Cavalcanti 1998, 2000, 2001; Novozhilov et al. 2001; 
Table 2 - Abundance of 24 species of myxomycetes on different organs of Elaeis guineensis Jacq. (Gurjaú Ecological Reserve, Pernambuco state, Brazil)

\begin{tabular}{|c|c|}
\hline Abundance class & Species \\
\hline Abundant (over 7\%) & Hemitrichia serpula. \\
\hline Common $(5-7 \%)$ & $\begin{array}{l}\text { Arcyria cinerea; Ceratiomyxa fruticulosa; Didymium anellus; } \\
\text { Metatrichia vesparia; Physarum compressum. }\end{array}$ \\
\hline Occasional (2-4\%) & $\begin{array}{l}\text { Ceratiomyxa sphaerosperma; Cribraria microcarpa; Didymium sp.; } \\
\text { Physarella oblonga; Physarum bogoriense; Physarum viride; Stemonitis fusca. }\end{array}$ \\
\hline Rare $(0.5-1 \%)$ & $\begin{array}{l}\text { Didymium clavus; Hemitrichia pardina; Perichaena chrysosperma; } \\
\text { Physarum album; Physarum crateriforme; Physarum gyrosum; } \\
\text { Physarum stellatum; Physarum sp. 1; Physarum sp. 2; Stemonitis splendens; } \\
\text { Stemonitopsis typhina. }\end{array}$ \\
\hline
\end{tabular}

Cavalcanti \& Mobin 2001, 2004). This species was abundant in the environments studied, sporulating on different living or dead organs (Tabs. 1-2). This is the first record of this species on oil palm trees in Brazil.

Records of associations with palm tree species in Brazil: A. vulgare; A. speciosa; M. flexuosa.

Distribution in Brazil: North (AM, PA, RR), Northeast (BA, CE, PB, PE, PI, RN), Center-West (DF), Southeast (RJ, SP), South (PR, SC, RS).

Metatrichia vesparia (Batsch) Nann.-Bremek. ex G. W. Martin \& Alexop., Myxomycetes 143 (1969).

(C) (4/LfDd)

This species is widely distributed throughout the world. In Brazil, this is the first record on oil palm trees, although it had already been encountered on palm trees in São Paulo and Piauí (Hochgesand \& Gottsberger 1996; Mobin \& Cavalcanti 1998, 2000; Cavalcanti \& Mobin 2004). It was common on E. guineensis and was found exclusively on the leaves of individuals in the Cuxio and Café Forests (Tabs. 1-2).

Records of associations with palm tree species in Brazil: A. vulgare; A. speciosa; M. flexuosa.

Distribution in Brazil: North (AM), Northeast (BA, PE, RN, SE), Southeast (RJ, SP), South (PR, $\mathrm{SC}, \mathrm{RS})$.

Perichaena chrysosperma (Curr.) Lister, Monogr. Mycetozoa: 196(1834). (R) $(1 / \mathrm{BctLv})$

Occurring in almost all regions of Brazil, $P$. chrysosperma was found sporulating on different organs of palm trees in the states of São Paulo and Piauí (Hochgesand \& Gottsberger 1996; Mobin \& Cavalcanti 1998, 2000; Cavalcanti \& Mobin 2004).
In this study, a single specimen was encountered on an oil palm tree, one of the few species found on living bract (Tabs. 1-2).

Records of associations with palm tree species in Brazil: A. vulgare; M. flexuosa.

Distribution in Brazil: Northeast (BA, PB, PE), Southeast (RJ, SP), South (SC).

Physarella oblonga (Berk. \& M. A. Curtis) Morgan, J. Cincinnati Soc. Nat. Hist. 19: 7 (1896).

(O) (3/TrkDd)

A cosmopolitan species, with several published records on palm trees in the states of Pernambuco, Paraíba and Piauí (Farr 1960; Cavalcanti \& Silva 1985; Mobin \& Cavalcanti 1998, 1999a). Ribeiro et al. (2002) cited P. oblonga as occurring on E. guineensis in the Gurjaú Ecological Reserve. Collected on dead trunks in the Café Forest, $P$. oblonga was occasionally found on oil palm trees in this study (Tabs. 1-2).

Records of associations with palm tree species in Brazil: A. speciosa; C. nucifera; $E$. guineensis; $M$. flexuosa.

Distribution in Brazil: North (AM,PA), Northeast (BA, PB, PE, PI, RN, SE), South (PR, SC, RS).

Physarum album (Bull.) Chevall., Fl. Gén. Env. Paris 1:336(1826).

(R) $(1 / \mathrm{LfDd})$

Widely distributed in Brazil, this species has been reported to occur on palm trees of the genus Astrocaryum in the states of São Paulo and Piauí, under the name $P$. nutans Pers. (Hochgesand \& Gottsberger 1996; Mobin \& Cavalcanti 1999a; Cavalcanti \& Mobin 2004). Rare on oil palm trees (on which it is recorded for the first time), a single 
specimen was obtained on a dead leaf in the Café Forest. The sporocarps of this specimen were quite typical (Tabs. 1-2).

Records of associations with palm tree species in Brazil: A. vulgare; Astrocaryum sp.

Distribution in Brazil: Northeast (BA, CE, PB, PE, PI, MA, RN, SE), Southeast (SP), South (PR, SC, RS).

Physarum bogoriense Racib., Hedwigia 37: 52 (1898).

(O) (1/ BctDd, 2/LfDd)

Predominantly tropical, $P$. bogoriense is widely distributed throughout Brazil, with records on palm trees in the states of Pernambuco and Piauí (Pôrto et al. 1985; Cavalcanti \& Mobin 2004). The plasmodiocarps -very typical- were only collected in the Café Forest, where this species occurred occasionally on oil palm trees, sporulating on bracts and dead leaves (Tabs. 1-2).

Records of associations with palm tree species in Brazil: A. speciosa.

Distribution in Brazil: Northeast (BA, PB, PE, PI, SE), Southeast (MG, SP), South (SC, RS).

Physarum compressum Alb. \& Schwein., Consp. Fung. Lusat. : 97 (1805).

(C) $(5 /$ IflDd $)$

Common on palm trees, with records in different states and regions, $P$. compressum is one of the four species that had been previously cited as occurring on oil palm trees in Brazil (Pôrto et al. 1985). It was found in the Café and São Braz Forests, predominately on inflorescences (Tab. 1), confirming its place in the floricolous group, as observed among the Zingiberales by Schnittler \& Stephenson (2002) in Ecuador, Costa Rica, and Puerto Rico. The form of the sporocarps varied considerably, yet within what should be expected for this species.

Records of associations with palm tree species in Brazil: C. nucifera; E. guineensis; Mauritia vinifera Mart.

Distribution in Brazil: Northeast (BA, CE, PE, MA, SE), Southeast (SP), South (PR, SC, RS).

Physarum crateriforme Petch., Ann. Roy. Bot. Gard. (Peradeniya) 4: 304 (1909). $\quad$ (R) (1/IflDd)

Rare in Brazil and on the studied substrate, this is its first record on oil palm trees, although it had already been found on unidentified palm trees in Pernambuco (Pôrto et al. 1985). The only specimen obtained was collected in the São Braz Forest, on a dead inflorescence, with very typical sporangia (Tabs. 1-2).

Distribution in Brazil: Northeast (PE, SE).
Physarum gyrosum Rostaf., Sluzowce Monogr.: 111 (1874).

(R) $(1 /$ TrkLv)

Reported only in Pernambuco, $P$. gyrosum had not yet been observed on palm trees in Brazil, and it occurred rarely on oil palm trees in this study. The specimen was typical of this species, one of the few that sporulated on living trunks (Tab. 1).

Distribution in Brazil: Northeast (PE).

Physarum stellatum (Massee) G.W. Martin, Mycologia 39 (4): 461 (1947).

(R) $(1 / \mathrm{LfDd})$

This species, which occurs in all regions of the country, was observed on palm trees in the states of São Paulo, Ceará, and Piauí (Hochgesand \& Gottsberger 1996; Alves \& Cavalcanti 1996; Mobin \& Cavalcanti 1998, 1999a; Cavalcanti \& Mobin 2004). Frequent in other areas of the Atlantic forest, mainly as a lignicolous species, it was rare on oil palm trees, being collected only once in the Café Forest, on dead leaves (Tabs. 1-2).

Records of associations with palm tree species in Brazil: A. vulgare; M. flexuosa.

Distribution in Brazil: North (AM, AP), Northeast (BA, CE, PE, PI, RN), Southeast (SP), South (PR).

Physarum viride (Bull.) Pers., Ann. Bot. (Listeri) 15: 6(1795).

(O) $(2 / \mathrm{LfDd})$

Physarum viride was occasionally encountered on oil palm trees and this is the first record of its occurrence on this kind of substrate. It is cited on other palm trees in the states of Amazonas, Piauí, and São Paulo (Farr 1985; Hochgesand \& Gottsberger 1996; Mobin \& Cavalcanti 1999a; Cavalcanti \& Mobin 2004).

The two specimens analyzed, collected on dead leaves in the Café Forest (Tab. 1), had the characteristics of var. aurantium (Bull.) Lister as referred to by Lado (2001) in the synonymy given for $P$. viride .

Records of associations with palm tree species in Brazil: A. vulgare; Arecastrum romanzoffianum (Cham.) Becc.

Distribution in Brazil: North (AM), Northeast (PE, PI, RN, SE), Southeast (SP), South (PR, SC).

\section{Physarum sp. 1}

(R) (1/LfDd)

Collected in the Café Forest. Sporocarps were very similar to those of $P$. stellatum, yet without the calcium impregnated peridium that characterizes this species. 
Physarum sp. 2

(R) (1/LfDd)

Collected on dead leaves in the São Braz

Forest, this specimen was colonized by fungi. Identification was limited to the genus level, although it was clearly different from the other species of Physarum studied.

Stemonitomycetidae - This subclass comprises only one order (Stemonitales) and one family (Stemonitaceae), with 16 genera and 202 species (Lado 2001). In this study, the three species found on E. guineensis belong to genera Stemonitis and Stemonitopsis.

Stemonitis fusca Roth, Bot. Mag. (Römer \& Listeri) 1(2): 26) (1787).

(O) (2/LfDd)

Cosmopolitan and widely distributed throughout the different regions of Brazil, this species was found solely on palm trees in Piauí (Mobin \& Cavalcanti 1998, 1999b; Cavalcanti \& Mobin 2004). Cavalcanti et al. (2006) mentions S. fusca in the Gurjaú Ecological Reserve, on different substrates. In this study, this species was occasionally encountered on oil palm trees, and the fruiting bodies of one of the specimens collected on leaves in the Café Forest, had the characteristics of S. fusca var. nigrescens (Rex) Torrend, currently listed as a synonym of $S$. fusca by Lado (2001).

Records of associations with palm tree species in Brazil: A. vulgare; C. prunifera; M. flexuosa.

Distribution in Brazil: North (AM, PA, RR), Northeast (BA, PB, PE, PI, RN, SE), Southeast (SP), South (PR, SC, RS).

Stemonitis splendens Rostaf., Sluzowce Monogr.: 195(1874).

(R) (1/TrkLv)

This cosmopolitan species is widely distributed in Brazil, with records in a different number of states, and in the Gurjaú Ecological Reserve (Cavalcanti et al. 2006). In this study, it was rare on oil palm trees, and was collected on living trunk in the Café Forest (Tabs. 1-2). The characteristics of its fruiting bodies are typical of this species, already reported to grow on palm trees in the state of Piauí (Mobin \& Cavalcanti 1998, 1999b; Cavalcanti \& Mobin 2004), but not yet on oil palm trees.

Records of associations with palm tree species in Brazil: M. flexuosa.

Distribution in Brazil: North (AM, PA), Northeast (AL, BA, CE, PE, PI, SE), Southeast (SP), South (PR, SC, RS).
Stemonitopsis typhina (F.H. Wigg.) Nann.Bremek., Nederlands Myxomyceten: 209 (1975).

\section{(R) (1/Trk Lv)}

Widely distributed in Brazil, this cosmopolitan species has been reported to occur on palm trees in the state of Piauí under the name Comatricha typhoides (Bull.) Rostaf. (Mobin \& Cavalcanti 1998; Cavalcanti \& Mobin 2004). Although it is cited by Cavalcanti et al. (2006) in the Gurjaú Ecological Reserve as sporulating on different substrates, S. typhina was rare on the oil palm trees analyzed in this study, and was collected on one living trunk (Tabs. 1-2).

Records of associations with palm tree species in Brazil: A. vulgare; A. speciosa; M. flexuosa.

Distribution in Brazil: North (AM, RR), Northeast (CE, PB, PE, PI, SE), Southeast (SP), South (PR, RS).

Species incidence and abundance in the microhabitat: The incidence of myxomycetes on $E$. guineensis was found to be high (40-80\%). On the individuals studied, sporocarps were distributed over almost all of the organs analyzed, except for fruits (Tab. 1). When comparing the myxobiota found on three savanna and alluvial forest palm tree species in the Sete Cidades National Park, Cavalcanti \& Mobin (2004) concluded that leaves are the most common organ for myxomycete occurrence on A. vulgare, $C$. prunifera, and $M$. flexuosa. On oil palm trees, incidence was higher on leaves, although it did not differ much from that on inflorescences.

The association of $A$. cinerea, $H$. serpula, $P$. chrysosperma, and $P$. compressum with palm trees does not seem to be occasional, as they are mentioned by almost all the authors who have examined the relationship between myxomycetes and species in the family Arecaceae. In the Sete Cidades National Park, Mobin \& Cavalcanti (1998, 2000) observed $70 \%$ incidence on $C$. prunifera (savanna) and $100 \%$ on M. flexuosa (alluvial forest), although they only obtained 34 and 98 specimens, respectively (16-26 species). When comparing the list of species associated to these palm trees, we observed that between $50 \%$ and $60 \%$ of those recorded on A. speciosa and M. flexuosa were present on the oil palm trees analyzed.

Species richness can be considered high for the oil palm trees analyzed; however, the species recorded are mostly rare or occasional (Tab. 2). As shown by Pôrto et al. (1985), Alves \& Cavalcanti (1996), Mobin \& Cavalcanti (1998, 1999a, 2000) and 
Cavalcanti \& Mobin (2004), H. serpula and A. cinerea are frequently associated with palm trees in northeastern Brazil. In the Ecological Reserve of the Atlantic Forest studied in the present study, $H$. serpula showed the highest levels of abundance and incidence on oil palm trees, confirming they prefer association with palm trees.

\section{References}

Albuquerque, U.P.1997. Folhas sagradas: plantas litúrgicas e medicinais nos cultos afro-brasileiros. Editora Universitária da UFPE, Recife, 195p.

Alves, M.H. \& Cavalcanti, L.H. 1996. Myxomycetes em palmeiras (Arecaceae). Acta Botanica Brasilica 1: 1-7.

Bezerra, A.C.C.; Cavalcanti, L.H. \& Dianese, J.C. 2009. Species of Hemitrichia (Trichiaceae, Myxomycetes) in Brazil. Mycotaxon 107: 35-48.

Bezerra, M.F.A.; Bezerra, A.C.C.; Nunes, A.T.; Lado, C. \& Cavalcanti, L. H. 2008a. Mixobiota do Parque Nacional de Itabaiana, SE, Brasil: Physarales. Acta Botanica Brasilica 22: 1044-1056.

Bezerra, M.F.A.; Medrado, W.T. \& Cavalcanti, L.H. 2008b. Coprophilous myxomycetes of Brazil: first report. Revista Mexicana de Micologia 27: 29-37.

Cavalcanti, L. H. 2002. Biodiversidade e distribuição de mixomicetos em ambientes naturais e antropogênicos no Brasil: espécies ocorrentes nas Regiões Norte e Nordeste. In: Araújo, E.L; Moura, A.N.; Sampaio, E.V.S.B.; Gestinari, L.M.S. \& Carneiro, J.M.T. (eds.). Biodiversidade, conservação e uso sustentável da flora do Brasil. Universidade Federal Rural de Pernambuco, Sociedade Botânica do Brasil, Recife. Pp. 209-216.

Cavalcanti, L.H.; Bezerra, A.C.C.; Costa, A.A.A.; Ferreira, I. N. \& Bezerra, M.F.A. 2008. Occurrence and distribution of the Ceratiomyxales (Myxomycetes) in Northeastern Brazil. Brazilian Archives of Biology and Technology 51: 971-980.

Cavalcanti, L. H. \& Mobin, M. 2001. Hemitrichia serpula var. piauiensis (Trichiaceae, Myxomycetes) - a new variety from Brazil. Acta Botanica Brasilica 15: 133-137.

Cavalcanti, L.H. \& Mobin, M.2004. Myxomycetes associated with palm trees at Sete Cidades National Park. Systematic and Geography of Plants 74: 109-127.

Cavalcanti, L.H. \& Putzke, J.1998. Myxomycetes da Chapada do Araripe (Crato, CE, Brasil). Acta Botanica Brasilica 12: 257-265.

Cavalcanti, L.H. \& Silva, J.V.1985. Myxomycetes da Paraíba III Physarales. In: Anais da 8 Reunião Nordestina de Botânica. Sociedade Botânica do Brasil, Recife. Pp. 199-205.

Cavalcanti, L.H.; Tavares, H.F.M.; Nunes, A.T. \& Silva, C.F. 2006. Mixomicetos do Centro de Endemismo
Pernambuco, Nordeste do Brasil. In: Pôrto, K.C.; Tabarelli, M. \& Almeida-Cortez, J.S.(coord.). Diversidade biológica e conservação de floresta atlântica ao norte do Rio São Francisco. V.14. Ministério do Meio Ambiente, Brasília. Pp. 53-74.

Costa, A.A.A.; Ferreira, I.N.; Tenório, J.C.G. \& Cavalcanti, L.H. 2009. Mixobiota de Floresta Atlântica: novas referências de Trichiales, Liceales e Stemonitales para o estado da Paraíba, Nordeste do Brasil. Acta Botanica Brasilica 23: 313-322.

Farr, M.L.1960. The Myxomycetes of the IMUR herbarium with special reference to Brazilian species. Universidade do Recife, Recife, 54p.

Farr, M. L.1976. Flora Neotropica. Organization for Flora Neotropica. New York Botanical Garden, New York. 304p.

Farr, M.L.1985. Notes on myxomycetes IV. Species collected in the Brazil and Japan. Nova Hedwigia 41: 167-175.

Hochgesand, E. \& Gottsberg, G.1996. Myxomycetes from the State of São Paulo, Brazil. Boletim do Instituto de Botânica 10: 11-46.

Lado, C.2001. Nomenmyx - A nomenclatural taxabase of Myxomycetes. Cuadernos de Trabajo de Flora Micológica Ibérica 16. Consejo Superior de Investigaciones Científicas Real Jardín Botánico, Madrid. 222p.

Lado, C. \& Pando, F.1997. Flora micológica ibérica. Myxomycetes I. Cramer, Berlim. 323p.

Lado, C. \& Teyssière, M. 1998. Myxomycetes from Equatorial Guinea. Nova Hedwigia 67: 421-441.

Lorenzi, H.; Souza, H.M.; Medeiros-Costa, J.T. \& Cerqueira, N.V.B. 1996. Palmeiras do Brasil nativas e exóticas. Plantarum, São Paulo. 432p.

Maimoni-Rodella, R.C. 2002. Biodiversidade e distribuição de mixomicetos em ambientes naturais e antropogênicos no Brasil: espécies ocorrentes nas Regiões Sudeste e Centro-Oeste. In: Araújo, E.L.; Moura, A.N.; Sampaio, E.V.S.B.; Gestinari, L.M S. \& Carneiro, J.M.T. (eds.). Biodiversidade, conservação e uso sustentável da flora do Brasil. Universidade Federal Rural de Pernambuco, Sociedade Botânica do Brasil, Recife. Pp. 217-220.

Martin, G.W.\& Alexopoulos, C.J. 1969. The Myxomycetes. University of Iowa Press, Iowa. 561p.

Martin, G.W.; Alexopoulos, C.J. \& Farr, M.L. 1983. The genera of Myxomycetes. University of Iowa Press, Iowa. 198p.

Mobin, M. \& Cavalcanti, L.H.1998. Myxomycetes ocorrentes sobre buriti (Mauritia flexuosa L.f., Arecaceae). Revista da Universidade do Amazonas, Série Ciências Biológicas 2/3: 43-51.

Mobin, M. \& Cavalcanti, L.H. 1999a. Physarales (Myxomycetes) do Parque Nacional de Sete Cidades (Piauí, Brasil). Hoehnea 26: 1-14. 
Mobin, M. \& Cavalcanti, L.H.1999b. Stemonitales (Myxomycetes) do Parque Nacional de Sete Cidades (Piauí, Brasil). Acta Botanica Brasilica 13: 139-148.

Mobin, M. \& Cavalcanti, L. H. 2000. Myxomycetes em carnaúba (Copernicea prunifera, Areaceae). Acta Botanica Brasilica 14: 71-75.

Mobin, M. \& Cavalcanti, L.H. 2001. Trichiaceae (Myxomycetes) do Parque Nacional de Sete Cidades (Piripiri, Piauí, Brasil). Hoehnea 28: 39-51.

Novozhilov, Y.K.; Schnittler, M.; Rollins, A.W. \& Stephenson, S.L. 2001. Myxomycetes from different forest types in Puerto Rico. Mycotaxon 77: 285-299.

Pôrto, K.C.; Cavalcanti, L.H. \& Correia, A.M.S. 1985. Incidência de Myxomycetes em Palmae. In: Anais do $33^{\circ}$ Congresso Nacional de Botânica, Universidade Federal de Alagoas. Pp. 181-187.

Putzke, J. 2002. Myxomycetes na Região Sul do Brasil. In: Araújo, E. L.; Moura, A.N.; Sampaio, E.V.S.B.;
Gestinari, L.M.S. \& Carneiro, J.M.T. (eds.). Biodiversidade, conservação e uso sustentável da flora do Brasil. Universidade Federal Rural de Pernambuco, Sociedade Botânica do Brasil, Recife. Pp. 221-223.

Ribeiro, S.M.; Cavalcanti, L.H.; Pereira, E.C.; Gusmão, N. B. \& Silva, N.H.2002. Detecção de atividade antibacteriana in vitro nos extratos brutos obtidos a partir do plasmódio de Physarella oblonga (Berk. \& Curt.) Morgan (Myxomycetes). Revista Brasileira de Farmacognosia 12: 100-102.

Schnittler, M. \& Stephenson, S.L. 2002. Inflorescences of Neotropical herbs as a newly discovered microhabitat for myxomycetes. Mycologia 94: 6-20.

Tenório, J.C.G.; Bezerra, M.F.A.; Costa, A.A.A. \& Cavalcanti, L.H.2009. Mixobiota do Parque Nacional Serra de Itabaiana, Sergipe, Brasil: Stemonitales. Acta Botanica Brasilica 23: 644-656.

Vilaró, M.C.1991. Myxomycetes de Cuba I. Revista del Jardín Botánico Nacional 12: 127-131. 